\title{
An Action Research on TPACK's Influence on Teachers of National Open University: Exemplified with an English Teacher of Zhejiang Radio \& TV University
}

\author{
Xiaoyang Shu \\ School of Foreign Languages, Zhejiang Radio \& TV University, Hangzhou, China \\ Email: sxy327love@126.com
}

Received 7 January 2016; accepted 22 January 2016; published 27 January 2016

Copyright (C) 2016 by author and OALib.

This work is licensed under the Creative Commons Attribution International License (CC BY). http://creativecommons.org/licenses/by/4.0/

cC) (i) Open Access

\begin{abstract}
TPACK (Technological Pedagogical Content Knowledge) is a kind of new knowledge required by teachers for technology integration in their subject teaching. With the connotation of TPACK including TCK, TPK and PCK, the project, exemplified with translation teaching, conducts an action research of an English teacher of Zhejiang Radio \& TV University on how she uses information technology to help conduct translation teaching, then integrates technology into translation teaching, and finally acquires and develops TPACK framework. At last, acquiring TPACK has a great effect on the perfection of teachers' knowledge system, the development of teachers' teaching ability and promotion of professional development of teachers.
\end{abstract}

\section{Keywords}

TPACK, Perfection of Teachers' Knowledge System, Action Research, Development of Teachers' Teaching Ability, Professional Development of Teachers

\section{Subject Areas: Education}

\section{Introduction}

21 Century has been witnessing a rapid and steady progress and innovation in technology, information and knowledge transfer. National Outline for Medium and Long-term Education Reform and Development (20102020) clearly states that modern information technology plays an innovative and important role in educational development. National Open University, a new university emerging in this era, needs redefining and redesigning in the field of educational context. Thus, with the official establishment of National Open University, I, a pro- 
fessional English teacher of Zhejiang Radio \& TV University, often ponder over the following questions: since academic and non-academic education of National Open University is mainly developed through public service platform [1], building a digital learning resources bank concentrated with teaching, research, management and service is a necessity in order to adapt to the development trend of modern information technology and internet technology. With the emergence of various mini-coursewares, microlectures, online courses, especially technology ability of some adult students which are better than those of mine, I feel a little bewildered, and even a little distressed. In this information era, how can I apply various educational technologies to improve and strengthen the students' learning? Therefore, in the paper, I, with an action research, intend to analyze my bewilderment and confusion when applying modern education technology into translation teaching. The possible solution to my confusion is to acquire and develop TPACK.

\section{Solutions-Acquiring and Developing TPACK}

With the above-mentioned questions, I conducted an action research on my own teaching (exemplified with translation course) through such ways as teaching journal, interviews, forum messages and etc. With this research method, I analyze my bewilderment and confusion when applying modern education technology during teaching. Through constant reflection on my own teaching process, I try to find ways to solve my bewilderment—acquiring and developing TPACK.

\section{The Interpretation of TPACK Based on Translation Course}

Technological Pedagogical Content Knowledge (TPACK), building on Shulman's construct of Pedagogical Content Knowledge (PCK) [2]-[4], not only emphasizes that teacher knowledge has the characteristics of versatility, complexity, and context knowledge, but regards itself as a theoretical framework for understanding teacher knowledge required for effective technology integration. At the heart of the TPACK framework, is the complex interplay of three primary forms of knowledge: Pedagogical Content Knowledge (PCK), Technological Content Knowledge (TCK), and Technological Pedagogical Knowledge (TPK) [5]. Mishra (2006) held that TPACK goes beyond seeing these three knowledge bases in isolation, but emphasizing the intersection of all three circles. Teaching is a kind of highly-complicated activity, which needs to attach great importance to various types of knowledge and their interrelationships [6] [7].

Translation course aims to develop the students' comprehensive language ability and translation competence, putting great emphasis on translation practice. However, the enclosed and teacher-oriented traditional teaching method pays more attention to language points, with lack of effective communication between students and teachers, between students, and between students and outside world and low interaction quality. With the rapid development of information technology, in order to integrate information technology with translation course, and in order to improve the students' interaction level and interaction quality in translation course, I try to redesign the teaching content and teaching method regarding translation course with a framework of TPACK (Figure 1).

1) With analyzing the students' characteristics, designing technological content knowledge based on translation course (TCK)

CK in the framework of TPACK is defined as Content Knowledge. Translation course aims to develop the students' translation competence through doing a large amount of translation practice [8]. Ma Huijuan (2010) [9]; Liu Miqing (2006) [10]; Wen Jun (2005) [11] once classified translation competence as bilingual competence, pragmatic competence, cultural competence, professional knowledge competence, research competence, strategy/skill competence and self-assessment/self-correction competence. But in fact, the contents of translation competence vary for different situations, stages and levels. According to knowing the characteristics of distance open education and distance learners, time-and-space separation between teachers and learners means that the remarkable change in teaching and learning of distance open education lies in the process of linking different information in order to make our knowledge system more specific [8]. Technological Content Knowledge (TCK) in the framework of TPACK refers to the knowledge how technology can create new representations for specific content [12]. Teachers must understand that, by using a specific technology, they can change the way learners practice [12], that is, technology may have an effect on or change content knowledge, and vice versa. Therefore, with the development of information technology, I include the competence of consulting information by means of advanced technology such as corpus and network tools in the translation competence framework. Besides, the 


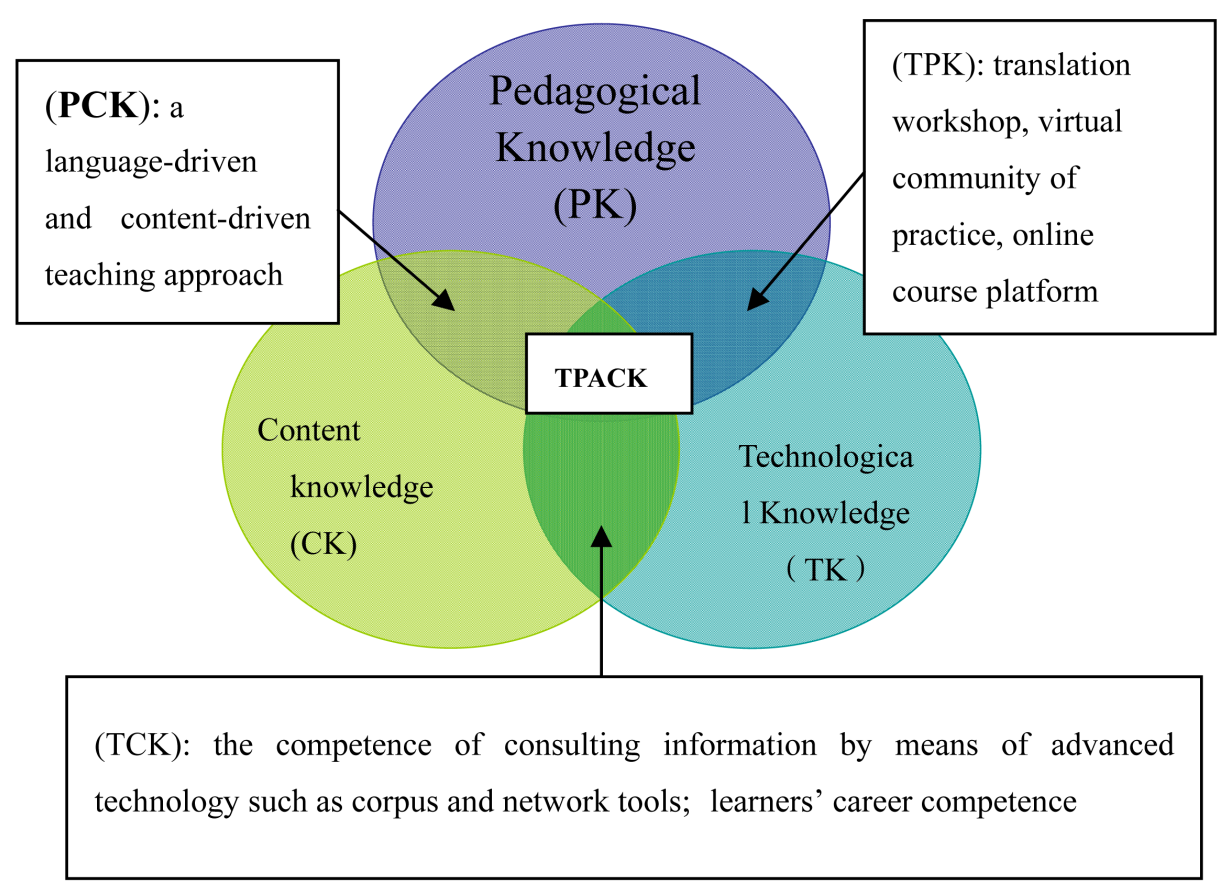

Figure 1. Translation teaching based on TPACK.

learners' career competence is covered. As we know, the technology can help simulate real translation ecological environment for distance learners, most of who are adult students with high self-cognition and emphasize course content integrated with personal experience, hoping learning this course can help them a lot in their work and daily life.

2) With Technological Pedagogical Knowledge (TPK), designing an ecological learning environment of translation course

Technology Knowledge (TK) in the framework of TPACK emphasizes modern media and network technologies integrated in course teaching at a deep level. Technological Pedagogical Knowledge (TPK) refers to the knowledge of how various technologies can be used in teaching, and to understanding that using technology may change the way teachers teach [12]. With TPK, an ecological learning environment of translation course with rich resources is built so as to promote the students' translation competence.

Building a translation workshop and a virtual community of practice. Using computer to simulate translation context (a translation workshop) in which students, forming a virtual community of practice by means of some interactive tools, such as QQ and BBS, can do various practices. The emphasis in the translation workshop is on the actual working out of the problems that are the same as those in real translation companies.

Building a network translation course platform. This platform includes multimedia display platform, online testing system, service for society, BBS and mobile learning. When meeting with problems, the students can help with each other through online real-time communication. Besides, the students can do mobile learning at any time and at any places. In a word, this network course platform is not only a moderate guide for class teaching, but also provides the students with a platform of self-tutorial and reference before the class and after the class.

3) Researching teaching strategy and designing Pedagogical Content Knowledge (PCK) based on translation course

Pedagogical content knowledge (PCK) in the framework of TPACK emphasizes the teachers should find various ways to deal with content knowledge. In addition to it, the teaching materials should be adapted or cut out in order to being fit for the students to learn [12]. A traditional translation teaching approach suggests the process of students finishing translation exercises after the teacher makes the explanation of original text, and then the teacher provides the reference version, which actually ignores the students' activeness and limits the students' space for self-exploration. 
Carrying out an interactive content-driven and language-driven teaching approach. This approach is studentoriented, emphasizing complementary interaction between in-class learning and after-class practice by means of information technology, and emotional interaction between students and between students and teachers, which can stimulate the students' enthusiasm and creativity and promote the students' comprehensive translation competence and teamwork awareness in this interactive teaching and learning environment. The teacher can choose "real" translation materials from the real world, with which the students can know more information about this world, express their professional thoughts and promote language proficiency. However, since large amounts of online teaching materials are disorderly and unsystematic, the teachers should, according to the students' requirement and ability, choose or adapt the materials to meet the students' requirements and ability.

\section{The Application of TPACK Framework into Translation Teaching}

\subsection{Information Technology: Assistance in Translation Teaching}

The study conducted an experiment on translation teaching based on TPACK framework in Open College of Zhejiang Radio \& TV University. At the beginning of the experiment, because of lack of class hours, I made some good multi-media coursewares to present teaching contents, and offered many relevant materials collected from internet to the students. I was proud of it. But later, I found out that most of the students only paid attention to the beautiful pictures of coursewares instead of my explanation of course contents. And some gave me an absent look. Seeing this, I felt a little bewildered. Maybe the students' voices can help me solve my problems.

I: Why don't you take notes during class? You can't follow me?

S1: The courseware you do is very interesting, so I only pay attention to the courseware.

S2: You speak so quickly that I can't figure it out.

S3: The contents involved in the class are too much, so I don't know what kind of notes I should take. If I take all the notes the teacher mentioned, time is not enough.

The students' answers help me find out the keys to my problems. I applied information technology in the translation class, whose aim is only to present contents and collect related information. Therefore, information technology was only assistance in translation teaching instead of really being integrated in the process of students' learning. In this approach, the students become the appreciators of coursewares, while I become a projectionist. For too many teaching resources (as to PCK, I didn't make it), I was only concerned about whether I could finish the courseware I had prepared, so I spoke too fast to deliver my thoughts logically and systematically. In fact, the more involuntary attention the students get, the fewer language materials they acquire. Therefore, I just turned "banging knowledge by means of people" into "banging knowledge by means of computer". So how can I make true technology integration into translation course and own TPACK?

\subsection{Normalization in Integration of Information Technology and Translation Course}

With the above-mentioned questions, I began to make a corresponding adjustment on how to integrate information technology into teaching. I read some articles on mind map by accident. I know major categories radiate from a central node, and lesser categories are sub-branches of larger branches. Categories can represent words, ideas, tasks, or other items related to a central key word or idea. Then I tried to recommend MindManager to the students. For example, when introducing such translation theories as famous translators and translation criteria, I ask the students to present the contents by MindManager. In addition to it, I encouraged the students to look through related materials by internet so as to broaden their horizon. Then the students' feedbacks are as follows:

S1: I feel this tool is a little troublesome at first, but later, I find it can help puzzle me out, for example, I use mind map to present translation criteria put forward by many famous translators, with which I believe I can bear it in mind.

S2: The teacher asks us to look through the relevant information and lets us decide which part we are interested in. It is quite different from the past: it was the teacher who decided the materials we must learn.

S3: Among so many online resources, I learn to how to choose important resources and share them with the students by means of the organized and clear mind map, which makes me proud.

The students' reactions make me realize that I can't use technology for technology's sake. In fact, the more information the teacher provides because of advanced technology, the less knowledge the students acquire [13]. With information technology integrated into translation practice to achieve disciplinary integration, technology, 
which is not an independent component of teaching, is really integrated into various components of teaching [12]. TPACK is not about technology, but treats content knowledge and effective teaching practice as priority [12].

Then, I tried the following strategies: 1) Dividing the students into some groups, from which a student host is chosen. Each group is a virtual community of practice and translation workshop. Hating or refusing being banged knowledge, the adult learners prefer learning in simulation environment, where they can solve the "real" problems that are similar to those in real life [12]. In a translation workshop, the students may do translation practice in the simulated environment just as in the translation company. If they meet questions, they can consult teachers, multiple dictionaries, and multiple previous translations and discuss with each other by means of QQ, BBS, E-mail and microblog. 2) Encouraging the students to take pictures by mobile phone if they find there are some problems on public signs, and then share them on internet by means of modern communication tools for discussion. These translation materials from real life provide us with actual materials. 3) Developing an interactive language-driven and content-driven teaching approach. The teacher can provide the students with some translation materials (adapted according to students' ability and requirements), from which each translation workshop can choose they are interested in or choose whatever text they prefer. Then in face-to-face tutorial class, each group makes a presentation on their translation exercise. Through this kind of translation practice, we hope the students can know more about the world, express their own ideas and improve their English proficiency. If they meet some words they are unfamiliar with, we encourage them to consult with mobile phone, which can make a deep impression on them. If we need to solve some problems on the students' discussion, I, together with the students, look through related materials by means of network course or the internet at once.

With some proudness, I wrote down some in my teaching dairy:

1) After a long time's learning, both I and the students are used to consulting internet when meeting some problems, and discussing and communicating with each other by means of modern communication tools, which seems to be an implicit, natural and normal behavior.

2) It seems that I apply technology only for technology's sake. I can't really integrate educational technology into teaching and learning of the course in the perspectives of magnitude, depth, and variety. Therefore, my view of technology integrated into teaching is solidified and static. In designing learning activities and carrying out teaching strategies, I failed to improvise on my class and integrate educational technology into teaching according to pedagogical knowledge [12]. In the later teaching and researches, I need to observe and discover those problems, adjust to teaching strategies and prove the ways to solve those problems.

\section{Reflection and Enlightenment}

With conducting an action research on translation course, I always reflect on the problems and bewilderment when integrating educational technology in translation teaching. The enlightenments I get are as follows:

1) In this information age, there are some changes in teachers' knowledge system, that is, technology will have an effect on teachers' knowledge system.

The TPACK framework, going beyond seeing content knowledge (CK), pedagogical knowledge (PK), and technological knowledge (TK) in isolation, is the complex interplay and dynamic balance between all three components [12]. Before, we only paid attention to changing content knowledge to adjust to new technology; however, at the moment we must consider the relationship between content knowledge and pedagogical knowledge with the emergence of the new technology. For example, how can we present content knowledge by means of technology; how can we relate the students to content knowledge; how can we deal with the relationship between the students, between the students and the teachers?

2) A corresponding change in the components of teachers' teaching ability

In this information society, the teachers' teaching ability is an organic marriage of teachers' knowledge system and teaching practice. TPACK is dynamic with TK in the TPACK framework changing constantly. Therefore, the teachers' teaching transferring ability [14] develops as the dynamic development of TPACK framework, and the teachers should learn how to solve the practical questions in the setting of informative teaching. Also in the TPACK framework, communication ability [14] between teachers and students, and between students in the setting of class and virtual teaching, represents diversified development. Besides, as to the teachers' teaching evaluation ability [14], it is a dynamic development assessment.

3) Promoting the teachers' professional development 
The teachers' professional development is a dynamic process of the teachers' enriching and perfecting themselves [14]. TPACK, an innovative knowledge framework, goes beyond seeing these three knowledge bases (content knowledge, pedagogical knowledge, technological knowledge) in isolation [12]. Therefore, TPACK framework is a kind of comprehensive, complex and multi-facet knowledge [5] [6]. With the characteristics of TPACK, the teachers are required to reflect on themselves, freely negotiating a world defined in terms of pedagogy, course content and information technology, for example, how to design new technology according to specific teaching context, and how to create new teaching space by means of new technology. The uniqueness of TPACK framework means different teachers' proficiency in pedagogical knowledge, technology and content knowledge varies. Therefore, the teachers' proficiency in TPACK is rather different from each other. The teachers can build learning community with cooperation and interaction, and make self-assessment with TPACK scale. They find out the problems in the process of cooperation, and gain each other's supports in the process of interaction, so that they can solve the problems together and understand teaching deeply. Hence, the teachers of 21 century become those who can apply advanced technology into teaching and acquire TPACK knowledge to influence the students' learning and teachers' teaching [5] [15], so that their professional development is promoted at last.

\section{Acknowledgements}

My thanks to the anonymous reviewers for reading and commenting on the early drafts of this article.

\section{Funding}

The project is supported by the Program for Research on Educational Technology of China (Grant No. 146241759), the Foundation of Distance Education: Development and Innovation (Grant No. 2014ZX02).

\section{References}

[1] Yan, B. (2012) A Speech Extract of a Grand Ceremony of China Distance Education of 2012.

[2] He, K.K. (2012) TPACK-The New Development of Ways and Methods of "Information Technology Integrated into Course” in America. E-Education Research, 33, 47-56.

[3] Shulman, L.S. (1986) Those Who Understand: Knowledge Growth in Teaching. Educational Researcher, 15, 4-14. http://dx.doi.org/10.3102/0013189X015002004

[4] Shulman, L.S. (1987) Knowledge and Teaching: Foundation of New Reform. Harvard. Educational Review, 57, 1-22.

[5] He, X.L. (2012) English Teacher’s Role Based on TPACK. Overseas English, 57-58.

[6] Mishra, P. and Koehler, M.J. (2006) Technological Pedagogical Content Knowledge: A Framework for Teacher Knowledge. Teachers College Record, 8, 1017-1054. http://dx.doi.org/10.1111/j.1467-9620.2006.00684.X

[7] Ruan, S.-G., Li, L.-Y. and Zheng, Y.-L. (2012) TPACK Framework: Research on "Modern Education Technology” Common Course Reform. Modern Educational Technology, 22, 36-41.

[8] Shu, X.Y. (2011) An Interactive Teaching Mode of Cultivating Learners' Translation Competence. Journal of Distance Education, 29, 106-110.

[9] Ma, H.J. and Guan, X.Z. (2010) Developing Learners’ Translation Competence (Chinese to English). Chinese Translators Journal, 31, 39-44.

[10] Liu, M.Q. (2006) A Guide to English-Chinese Translation Skills. China Translation \& Publishing Corporation, Beijing.

[11] Wen, J. (2005) A Study on the Model of Translation Curriculum-Translation-Competence-Centered Approach. China History and Literature Publishing Corporation, Beijing.

[12] American Association of Colleges of Teacher Education and Technology (2011) Handbook of Technological Pedagogical Content Knowledge (TPACK) for Education. Education Science Publishing House, Beijing, 21-309.

[13] Hong, W. (2012) An Analysis of and Reflections on PPT Courseware Dependency in College FLT Classroom. Foreign-Assisted Foreign Language Education, 147, 76-80.

[14] Wang, W.J. and Wang, W.J. (2012) Practice Analysis of Teachers' Informationized Teaching Ability. Modern Distance Education, 26, 67-74.

[15] Zhan, Y. and Ren, Y.Q. (2010) The Literature Review of Concept and Current Researches in Technological Pedagogical and Content Knowledge. Journal of Distance Education, 28, 78-87. 